\title{
REVIEW
}

\section{Targeting autophagy in thyroid cancers}

\author{
Weijun Wei1,2, Heather Hardin³ and Quan-Yong Luo' \\ 1Department of Nuclear Medicine, Shanghai Jiao Tong University Affiliated Sixth People's Hospital, Shanghai, China \\ 2Shanghai Jiao Tong University School of Medicine, Shanghai, China \\ 3Department of Pathology and Laboratory Medicine, University of Wisconsin School of Medicine and Public Health, Madison, Wisconsin, USA \\ Correspondence should be addressed to Q-Y Luo: luoqy@sjtu.edu.cn
}

\begin{abstract}
Thyroid cancer is one of the most common endocrine malignancies. Although the prognosis for the majority of thyroid cancers is relatively good, patients with metastatic, radioiodine-refractory or anaplastic thyroid cancers have an unfavorable outcome. With the gradual understanding of the oncogenic events in thyroid cancers, molecularly targeted therapy using tyrosine kinase inhibitors (TKIs) is greatly changing the therapeutic landscape of radioiodine-refractory differentiated thyroid cancers (RR-DTCS), but intrinsic and acquired drug resistance, as well as adverse effects, may limit their clinical efficacy and use. In this setting, development of synergistic treatment options is of clinical significance, which may enhance the therapeutic effect of current TKIs and further overcome the resultant drug resistance. Autophagy is a critical cellular process involved not only in protecting cells and organisms from stressors but also in the maintenance and development of various kinds of cancers. Substantial studies have explored the complex role of autophagy in thyroid cancers. Specifically, autophagy plays important roles in mediating the drug resistance of small-molecular therapeutics, in regulating the dedifferentiation process of thyroid cancers and also in affecting the treatment outcome of radioiodine therapy. Exploring how autophagy intertwines in the development and dedifferentiation process of thyroid cancers is essential, which will enable a more profound understanding of the physiopathology of thyroid cancers. More importantly, these advances may fuel future development of autophagy-targeted therapeutic strategies for patients with thyroid cancers. Herein, we summarize the most recent evidence uncovering the role of autophagy in thyroid cancers and highlight future research perspectives in this regard.
\end{abstract}

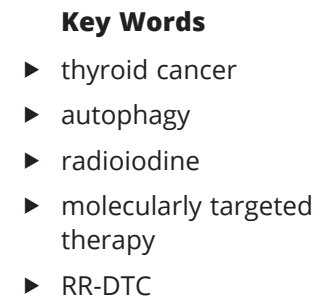

Endocrine-Related Cancer (2019) 26, R181-R194

\section{Introduction}

Thyroid cancer is the fifth most common cancer in women in the United States and is the most commonly diagnosed cancer before the age of 30 years among women in China (Chen et al. 2016). Although thyroid cancer is generally considered as an indolent tumor, it has a broad range of clinical behaviors ranging from an indolent tumor under the umbrella term of differentiated thyroid cancer (DTC) to more aggressive types (i.e., anaplastic thyroid cancer (ATC) and medullary thyroid cancer (MTC)). DTC accounts for more than 95\% of thyroid cancers and contains two major subtypes (i.e., papillary thyroid cancer (PTC) and follicular thyroid cancer (FTC)). While patients with lower risk diseases or benign thyroid nodules should not be overtreated, those with advanced diseases should be given more aggressive and efficacious treatments. Currently, a combination of surgery, radioactive iodine (c) 2019 Society for Endocrinology Published by Bioscientifica Ltd. Printed in Great Britain 
(RAI, 131I) and subsequent TSH suppression therapy is the mainstay of therapy for most DTC patients (Wei et al. $2018 b$ ). However, due to tumor dedifferentiation and concomitant loss of sodium/iodide symporter (NIS), certain thyroid cancer patients are insensitive or resistant to RAI therapy (Song et al. 2015). Although rare, ATC is the most aggressive form of thyroid cancers and is a clinical challenge owing to its pleomorphic histopathological features and rapid progression (Ragazzi et al. 2014, Keutgen et al. 2015, Tiedje et al. 2018).

The MAPK oncogenic pathway is closely involved in the proliferation, invasion and differentiation status of thyroid cancers (Fig. 1; Xing 2013). BRAF (v-raf murine sarcoma viral oncogene homolog B) is one of the wellcharacterized members of the MAPK pathway and somatic BRAF mutation, especially BRAFV600E mutation, occurs in up to $50 \%$ of PTCs and 45\% of ATCs (Xing 2013, Landa et al. 2016, Molinaro et al. 2017, Sandulache et al. 2017). As such, molecularly targeted therapy suppressing oncogenic proteins like BRAFV600E has increasingly been used for patients with radioiodine-refractory differentiated thyroid cancer (RR-DTC). Currently, vemurafenib and dabrafenib are two selective BRAFV600E inhibitors under clinical investigation for DTC patients harboring BRAFV600 mutation. In addition, two multi-kinase inhibitors with antiangiogenic properties, sorafenib and lenvatinib, have been licensed for treating RR-DTC and showed advantages in terms of progression-free survival. However, drug resistance and adverse effects associated with the singleagent treatment often lead to termination of the targeted therapy (Shen et al. 2014). Furthermore, the impact of these TKIs on overall survival of patients with RR-DTC

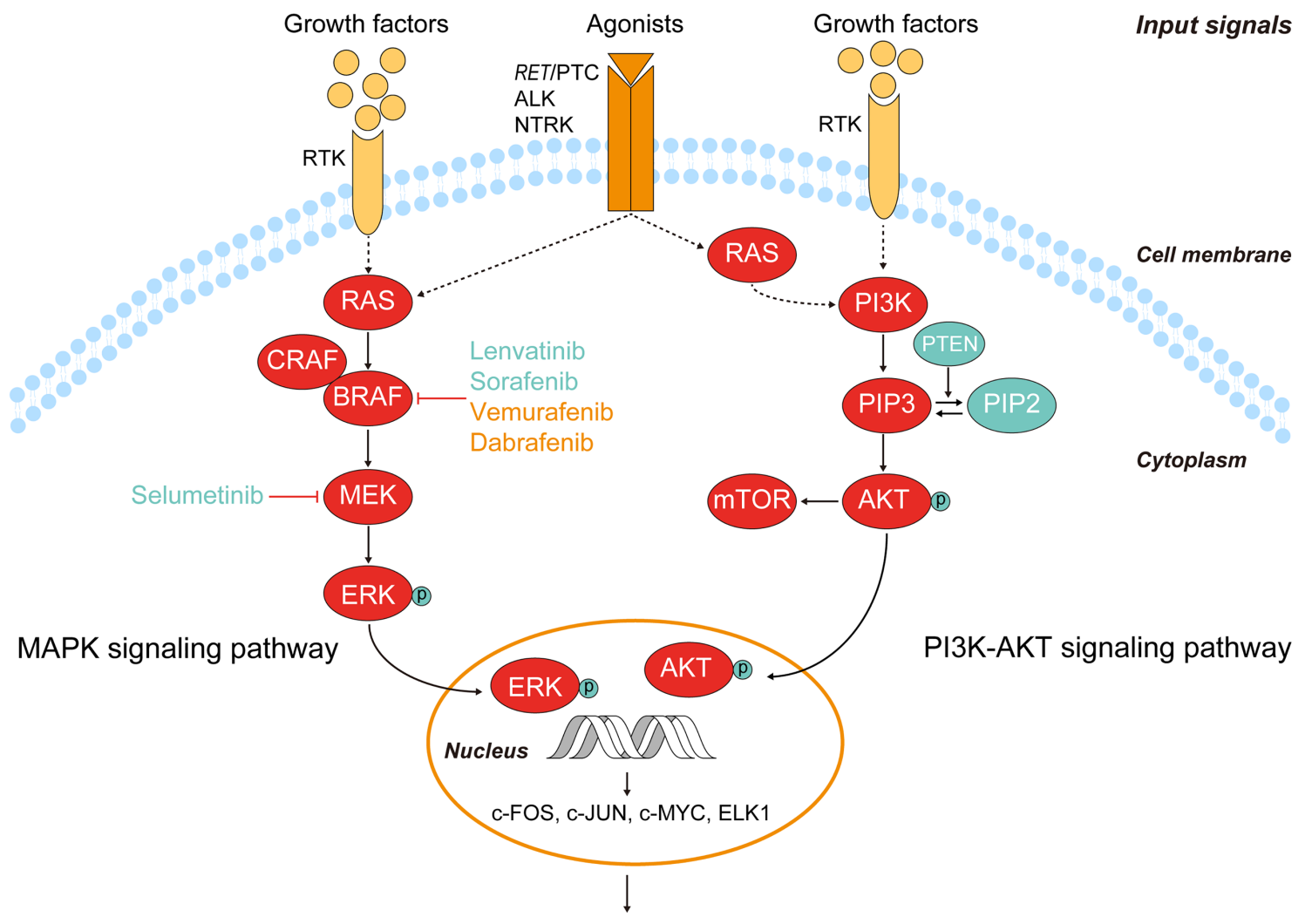

Proliferation Dedifferentiation Progression Poor prognosis Output effects

\section{Figure 1}

The MAPK and PI3K oncogenic signaling pathways are the main signaling cascades implicated in the thyroid cancer initiation, progression and dedifferentiation. The genetic mutation in the BRAF gene most commonly results in amino acid transformation at the 600 locus in the BRAF protein. The mutated BRAF (i.e., BRAFV60E) has enzymatic function and transmits messages by phosphorylating downstream protein MEK. BRAFv600E mutation in the thyroid may lead to significant reduction of proteins responsible for radioiodine uptake in both mouse models and in humans. Inhibitors blocking either mutated BRAF and/or MEK restore RAI uptake and prolong retention of radioiodine in the thyroid cancer cells. In addition to the MAPK signaling cascade, the PI3K pathway is also involved in the initiation and progression of thyroid cancers. PTEN switches off PI3K signaling by dephosphorylating PIP3 and therefore is a tumor suppressor. ALK, anaplastic lymphoma kinase; BRAF, rapidly accelerated fibrosarcoma type-B or v-raf murine sarcoma viral oncogene homolog B; MAPK, mitogen-activated protein kinase; NTRK, neurotrophic receptor tyrosine kinase; PI3K, phosphatidylinositol 3-kinase; PIP2, phosphatidylinositol 4,5-bisphosphate; PIP3, phosphatidylinositol-3,4,5-trisphosphate; PTEN, phosphatase and tensin homolog deleted on chromosome 10; RAS, rat sarcoma; RET, rearranged during transfection; RTK, receptor tyrosine kinase. A full color version of this figure is available at https://doi.org/10.1530/ERC-18-0502. 
has not been proven yet. Meanwhile, redifferentiation of RR-DTC emerges as a very promising approach to restore NIS expression and to enable ${ }^{131}$ I therapy (Ho et al. 2013, Rothenberg et al. 2015, Dunn et al. 2018). Nonetheless, novel strategies that can enhance the efficacy of TKIs and/or overcome resistance of TKIs are in urgent need to refine the clinical management of RR-DTCs and ATCs.

Macroautophagy (hereafter referred to as autophagy) is a process that captures and degrades intracellular components in lysosomes, thereby sustaining metabolic homeostasis and promoting the growth of a broad spectrum of cancers under certain conditions. Autophagy not only occurs upon nutrient deprivation to supply cells with building blocks but also occurs under nutrientrich conditions to mediate the removal of superfluous or damaged organelles and potentially toxic protein aggregates (White et al. 2015, Klionsky et al. 2016). Mitophagy is a selective form of autophagy that mediates the removal of mitochondria. Loss of mitochondrial membrane potential $(\Delta \Psi \mathrm{m})$ and mitochondrial fragmentation generally precede mitophagy (Youle \& Narendra 2011). The role of autophagy in sustaining metabolism and in promoting tumorigenesis has been widely investigated in multiple types of cancers (Guo et al. 2013, Strohecker et al. 2013, Karsli-Uzunbas et al. 2014, Yang et al. 2018). Although the detailed role of autophagy in the pathogenesis of thyroid cancer is not yet elucidated (Netea-Maier et al. 2015), recent studies shed light on the underlying mechanisms of autophagy in regulating the development and dedifferentiation of thyroid cancers (Plantinga et al. 2016, Tesselaar et al. 2017a, Tesselaar et al. 2018). Besides, dysregulated autophagy is closely involved in the resistance of small-molecule drugs (e.g., vemurafenib) in thyroid cancers (Wang et al. 2017, Wei et al. 2017). We herein review the potential role of autophagy in mediating the initiation, development and progression of thyroid cancers and highlight how autophagy interferes with the dedifferentiation process of thyroid cancers. Insights from the current evidence may provide the rationale for manipulating autophagy activity in treating thyroid cancers and in redifferentiating RR-DTC either as a standalone method or in combination with clinically available TKIs.

\section{Autophagy in initiation and development of thyroid cancers}

It is conceivable that both autophagy and mitophagy are linked to the initiation and development of thyroid cancers. Several major genomic mutations and/or rearrangements accounting for the occurrence of thyroid cancers may directly or indirectly regulate the activity of autophagy in thyroid cancers. Additionally, somatic mutations/deletions of mitochondrial DNA and alteration of mitochondrial biogenesis are associated with the carcinogenesis of a portion of Hürthle cell tumors, which are characterized by the cytoplasmic accumulation of abundant mitochondria (Maximo et al. 2012). As a specific type of autophagy dealing with redundant mitochondria (Youle \& Narendra 2011), mitophagy plays an important role in the evolution of Hürthle cell tumors (Yi et al. 2017).

PTEN (phosphatase and tensin homolog deleted on chromosome 10) is a tumor suppressor but its function is disabled in several human cancers. Although endogenous expression of HRASG12v alone is insufficient to drive thyroid tumorigenesis (Chen et al. 2009), and thyroidspecific knock-in of BRAFV600E induces mostly benign lesions (Franco et al. 2011), loss of p53 or concomitant loss of function of PTEN and p53 could induce initiation and progression of ATC (Antico Arciuch et al. 2011, McFadden et al. 2014). In addition, PTEN is a critical regulator in the development and progression of FTC and follicular adenomas (Yeager et al. 2007, Guigon et al. 2009). PTEN is also closely associated with Cowden syndrome, an autosomal dominant disorder that predisposes to female breast cancer, thyroid cancer and other cancers (Zbuk \& Eng 2007). PTEN-induced putative kinase 1 (PINK1)-Parkin pathway involves maintaining mitochondrial integrity and functions through triggering the mitophagy of abnormal mitochondria (Park et al. 2006, Grenier et al. 2013). Lee and colleagues found that Hürthle tumor cells had intact non-selective autophagy but ineffective mitophagy activity, which therefore resulted in decreased turnover of aberrant mitochondria and carbonyl cyanide $m$-chlorophenylhydrazone (CCCP)-induced cell death (Lee et al. 2015). The authors further reported that expression of WT Parkin sensitized Hürthle cell lines to CCCP-induced cell death (Lee et al. 2015). Recent studies also revealed the role of autophagy in regulating the dynamics of ciliogenesis (Pampliega et al. 2013, Satir \& Pampliega 2016). Interestingly, although PTCs have long cilia, Hürthle cells found either in benign nodules or in malignant thyroid diseases were devoid of primary cilia (Lee et al. 2016). Loss of cilia seemed to be a characteristic feature of Hürthle cells and was associated with high levels of autophagosome biogenesis, and inhibition of autophagy restored ciliogenesis in the Hürthle cell lines (Lee et al. 2016).

Succinate dehydrogenase (SDH) is a unique membrane-bound enzyme that plays dual functions in both the Krebs cycle for succinate oxidation and the https://erc bioscientifica com

https://doi.org/10.1530/ERC-18-0502 (c) 2019 Society for Endocrinology Published by Bioscientifica Ltd. Printed in Great Britain 
respiratory chain for electron transfer to the terminal acceptor ubiquinone. SDH contains two catalytic subunits (SDHA and SDHB) and two structural anchors (SDHC and SDHD). Generally, genes encoding the four subunits of SDH are believed to be tumor suppressor genes (Gimm et al. 2000). A recent study elucidated that germline SDH variants, SDHD-G12S and SDHD-H50R, may result in the oxidation and loss of function of PTEN (oxidized PTEN) in FTC cell lines (Yu et al. 2015). The same team further elaborately found that both normal thyroid follicles and PTC cells expressing SDHD-G12S or -H50R variants grew faster than SDHD-WT cells (Yu et al. 2017). Furthermore, SDHD-G12S or -H50R variants suppressed autophagy in normal thyroid follicles and PTC cells by downregulating the expression of FOXO3a target genes (BECN1 and ATG12 in TPC-1 cells and BECN1 in Nthy-Ori-3 cells) in a PTEN-dependent manner (Yu et al. 2017). In line with previously proposed models (Netea-Maier et al. 2015), these results together highlight the suppressive role of autophagy in the initiation of thyroid cancer or in the early phases of its development.

Coatomer protein complex I (COPI) complex members are involved in autophagy in several cancer types including in prostate, breast and ovarian carcinoma cells (Razi et al. 2009, Shtutman et al. 2011, Claerhout et al . 2012). By screening with a siRNA oligonucleotide library in thyroid cancer cells (BCPAP) and normal human thyrocytes (Nthy-ori 3-1), Anania et al. initially found that Cyclin D1, MASTL and COPZ1 (coatomer protein complex $\zeta 1)$ are three oncogenes for thyroid cancer, and inhibition of these three genes reduced the viability of several thyroid tumor cell lines, regardless of the histotype or oncogenic lesion (Anania et al. 2015). Further study showed that COPZ1 silencing was associated with significantly increased LC3 puncta and conversion of the endogenous LC3-I to LC3-II in TPC-1 and 8505C cells (Anania et al. 2017). Actually, COPZ1 depletion caused abortive autophagy as an increase of SQSTM1/p62 in both COPZ1-depleted cell lines was observed. More importantly, COPZ1 depletion induced apoptotic cell death and suppressed tumor growth in 8505C ATC xenografts. These results indicated that downregulation of COPZ1 and concomitant disruption of autophagy may be an attractive approach for treating thyroid cancers.

Epithelial-to-mesenchymal transition (EMT) is associated with the development and invasion of thyroid cancers, especially PTC and ATC (Hardy et al. 2007, Hardin et al. 2017). EMT and autophagy are two distinct events but a cross-talk exists between these two events in a controversial way (Marcucci et al. 2017).
Cadherin-6 (CDH6), a type 2 cadherin, is a target of transforming growth factor- $\beta$ (TGF- $\beta$ ) signaling pathway and therefore is a marker of EMT in thyroid cancers (Sancisi et al. 2013). More recently, Gugnoni et al. reported that silencing of CDH6 expression not only profoundly attenuated EMT features but also induced LC3 and GABARAP lipidation in PTC cells, which was accompanied by a decreased level of p-AKT. In parallel, CDH6 is a potential marker for predicting distant metastases from PTC (Gugnoni et al. 2017). These results together potentially indicate the role of CDH6 in mediating PTC progression and the underlying interaction of EMT and autophagy behind this phenotype.

One typical character of DTC is the consistent femaleto-male ratio of 3:1 across almost all geographic areas and ethnicities; one of the potential factors accounting for the gender disparity is estrogen receptors (Manole et al. 2001). A recent study has elucidated that estrogen could induce autophagy in PTC in an estrogen receptor $\alpha$ dependent manner, which could, therefore, provide energy and building blocks (Fan et al. 2015). By binding to nuclear receptors (TRs, including TR $\alpha$ and TR $\beta$ ), thyroid hormone is a potent regulator of cellular and tissue metabolism throughout the body. Thyroid hormone, especially $\mathrm{T}_{3}$, has been shown to exert profound effects on mitochondrial biogenesis and energy metabolism (Weitzel \& Iwen 2011, Sinha et al. 2015). $T_{3}$ induced autophagic flux in hepatocytes and inhibited HBV-encoded X protein ( $\mathrm{HBX}$ )induced hepatic carcinogenesis in mice (Chi et al. 2017). However, thyroid hormone-related autophagy in the development of thyroid cancers remains to be determined.

\section{Autophagy in molecularly targeted therapy of thyroid cancers}

As aforementioned, numerous genetic alterations including BRAFV600 mutation are involved in the tumorigenesis of thyroid cancers (Cabanillas et al. 2016, Fagin et al. 2016). In clinical trials, BRAFV600E inhibitors have achieved preliminary success in the treatment of PTCs (Kim et al. 2013, Dadu et al. 2015), and the antitumor activity of vemurafenib with a partial response rate of $38.5 \%$ for patients with BRAFV600E-positive PTC was observed in a recent phase 2 clinical trial (Brose et al. 2016). Molecularly targeted therapies also emerge as the standard of care for ATC patients either with metastatic or radiation-resistant diseases (Hanna et al. 2018, Iyer et al. 2018, Subbiah et al. 2018). However, there is increasing evidence that thyroid cancer patients undergoing TKI 
treatment may ultimately escape the effects of therapy and then develop resistance (Kreissl et al. 2019).

A recent study has revealed that higher expression levels of all autophagy-related proteins were observed in BRAFV600E mutation-positive PTCs compared to those without the BRAFV600E mutation (Kim et al. 2017). Similarly, BRAF or RAS mutant thyroid cancer cell lines tend to have a higher level of autophagy following drug treatment (Bikas et al. 2015, Plews et al. 2015). Wei et al. recently found that following vemurafenib treatment, mitochondrial respiration and ATP production in thyroid cancer cells (K1 cells) increased significantly (Wei et al. 2017), indicating increased mitochondrial metabolism as a potential mechanism for vemurafenib resistance. Obatoclax, an experimental Bcl2 inhibitor, could successfully overcome vemurafenib-induced resistance by reducing ATP production and suppressing the activity of autophagy in thyroid cancer cells (Wei et al. 2017). Champa et al. further found that obatoclax induced necrosis of thyroid cancer cells by localizing to the lysosomes, inducing loss of acidification and blocking lysosomal fusion with autophagic vacuoles (Champa et al. 2016). Hydroxychloroquine (HCQ), a derivative of chloroquine (CQ), can inhibit lysosomal acidification and prevent the degradation of autophagosomes (Manic et al. 2014), thereby suppressing autophagy. Both CQ and HCQ are currently under clinical trials to inhibit autophagy (Levy et al. 2017). Wang et al. found that vemurafenib induced a high level of autophagy in BRAFmutation-positive thyroid cancer cells and inhibition of autophagy by either HCQ or knockdown of essential autophagy genes augmented the efficacy of vemurafenib (Wang et al. 2017). In this study, the authors revealed that vemurafenib-induced autophagy was independent of the MAPK signaling pathway but was associated with endoplasmic reticulum (ER) stress response activation. These results indicate that autophagy-inhibiting strategies are thus predicted to inhibit mitochondrial metabolism or to enhance the cytotoxic effect of vemurafenib.

From current evidence, it seems that autophagy plays a double role in mediating the anti-thyroid cancer effect of sorafenib (Lin et al. 2012, Yi et al. 2018). Different from sorafenib and lenvatinib which have multiple targets, apatinib is another TKI selectively targeting vascular endothelial growth factor receptor 2 (VEGFR-2). Two recent studies have reported the potent therapeutic efficacy of apatinib in treating RR-DTCs (Lin et al. 2017, Zhang et al. 2018). Despite the exciting disease control rate $(100 \%)$ and objective response rate $(70.0 \%)$ for the $500 \mathrm{mg}$ qd schedule, the frequent and severe adverse events may limit its consecutive clinical use (Zhang et al. 2018). In a preclinical setting, Feng et al. reported that inhibition of apatinib-induced autophagy using CQ led to increased apoptosis of ATC cells both in vitro and in vivo (Feng et al. 2018), indicating the superior therapeutic effect of the combinational treatment. Upon further clinical investigation, this strategy may serve as a promising treatment option for both RR-DTC and ATC, which may enhance the efficacy of apatinib while alleviating the toxicities caused by high-dose apatinib monotherapy.

It is notable that several natural compounds are capable of suppressing thyroid cancers, such as mulberry anthocyanins (Long et al. 2018) and flavokawain B (He et al. 2018). Flavokawain B-induced autophagy plays a pro-survival role in several malignancies including thyroid cancers (He et al. 2018, Wang et al. 2018a). Consequently, combinational administration of flavokawain B and CQ resulted in more profound inhibition of tumor growth in FTC models (He et al. 2018). Honokiol is another bioactive natural compound obtained from Magnolia officinalis (Prasad \& Katiyar 2016). Recently, Lu et al. showed that honokiol treatment could suppress cell growth, induce cell cycle arrest, enhance the induction of both caspasedependent and -independent apoptosis, and autophagy in ARO and SW579 cell lines. But honokiol treatment did not induce autophagic flux in WRO cells. The study also revealed that honokiol could affect the regulation of MAPK signaling pathways in the ATC, FTC and PDTC cells (Lu et al. 2017). However, a recent study indicated that the ARO cell line matches HT-29 colon cancer cell line, which was probably caused by laboratory cross-contamination (Schweppe et al. 2008). Therefore, key experiments using contaminated ATC cell lines might have to be repeated with better characterized ATC cell lines (Lu et al. 2017, He et al. 2018).

In recent years, accumulating evidence has indicated the potential role of miRNAs and lncRNAs as theranostic targets in thyroid cancers (Wei et al. 2016, Zhang et al. 2016). Specifically, miR-125b is downregulated in the majority of follicular thyroid carcinomas and adenomas (Wang et al. 2018b). Overexpression of miR-125b sensitized thyroid cancer cells to cisplatin and sorafenib. Moreover, overexpression of miR-125b enhanced the therapeutic effect of cisplatin in in vivo studies, which was partially mediated by downregulation of Foxp3 and the resultant increased activity of autophagy induced by stimulated Atg7 (Wang et al. 2018b). Similarly, overexpression of lncRNA GAS8-AS1 could inhibit the proliferation of PTC cells and induce autophagy simultaneously, and silencing of ATG5 rescued such inhibitory effect caused by 
lncRNA GAS8-AS1 (Qin et al. 2018). In contrast, miR-30d negatively regulated cisplatin-activated autophagic response by downregulating BECN1, as a result, sensitizing ATC cells to cisplatin treatment both in vitro and in vivo (Zhang et al. 2014). Considering these promising yet controversial results, we would like to advocate the use of comprehensive detection and intervention methods when examining the role of autophagy in mediating the treatment outcome of small-molecular therapeutics in thyroid cancers (Wei et al. 2018a).

\section{Autophagy in redifferentiation of radioiodine-refractory thyroid cancers}

Findings from a large TCGA study showed that PTCs with BRAFV600E mutation were associated with a less differentiated state, for instance, loss of NIS expression (Cancer Genome Atlas Research Network 2014). It is gratifying that selective MEK inhibitor selumetinib and BRAF inhibitor dabrafenib showed redifferentiation effects and enhanced ${ }^{131}$ I uptake in patients with RR-DTC (Ho et al. 2013, Rothenberg et al. 2015). More recently, Huillard and colleagues investigated the ability of vemurafenib in inducing tumor redifferentiation and in restoring RAI uptake in an 83-year-old man with BRAFV600E-mutant RR-DTC and found that vemurafenib and dabrafenib could significantly enhance RAI uptake and reduce ${ }^{18 F-F D G}$ uptake (Huillard et al. 2017). The redifferentiation effect of vemurafenib was further validated by a most recent study (Dunn et al. 2018), in which four of the ten evaluable RR-DTC patients responded to vemurafenib treatment likely by upregulating thyroid-specific gene expression. In a preclinical study, Chakravarty et al. reported the efficacy of MAPK pathway inhibitors in restoring RAI uptake in mice (Chakravarty et al. 2011). However, another preclinical study reported the discordance of MEK inhibition and BRAF inhibition in inducing iodine uptake in ATC models (ElMokh et al. 2018).

More recently, several studies elucidated the potential role of autophagy in mediating the dedifferentiation of DTC and the clinical efficacy of ${ }^{131}$ I therapy. Clinically, Plantinga et al. initially showed that genetic variations in ATG16L1 (300Ala $(G)$ allele of ATG16L1) and in ATG5 (ATG5 single nucleotide polymorphisms rs2245214) were associated with a higher probability to develop thyroid carcinoma (Huijbers et al. 2012, Plantinga et al. 2014). The same group then found that although LC3-I intensity and LC3-II-positive puncta were not associated with thyroid cancer pathology except for a small group of ATC patients, both indexes were associated with clinical response to ${ }^{131}$ I therapy. More importantly, while membranous SLC5A5 (NIS) expression was decreased in tumors with low autophagy activity, the expression of SLC5A5 was strongly elevated in tumors with high numbers of LC3-II-positive puncta, indicating autophagy has an important impact on the dedifferentiation of thyroid cancers (Plantinga et al. 2016).

As we all know, digitalis-like compounds are wellcharacterized regimens in the treatment of heart failure and atrial arrhythmia (Prassas \& Diamandis 2008). Tesselaar et al. found that digitalis-like autophagyactivating compounds, digoxin in particular, restored NIS expression and iodide uptake in thyroid cancer cell lines, and a follow-up study revealed that upregulation of NIS was mediated by intracellular $\mathrm{Ca}^{2+}$ and FOS activation (Tesselaar et al. 2017a). Based on this preliminary evidence that digitalis-like compounds had beneficial effects in redifferentiating RR-DTC, Tesselaar et al. also investigated this effect using ATC cell lines (Tesselaar et al. 2018). The authors observed reduced autophagy activity in ATC tissues and found that while several TKIs (e.g., selumetinib) failed to restore NIS expression, most of the tested digitalis-like compounds (e.g., digoxin) were able to induce NIS at both mRNA and protein levels in the two tested ATC cell lines (Cal-62 and 8505C), which was further accompanied by increased 125I uptake (Tesselaar et al. 2018).

These results together demonstrate that the activity of autophagy may serve as a marker to predict the therapeutic response of 131I treatment. Furthermore, investigation of the role of autophagy in the dedifferentiation process of thyroid cancers could potentially facilitate development of novel therapeutics to treat and to redifferentiate RR-DTCs and ATCs. Considering that digitalis-like compounds have been used in clinic for many years, they, therefore, represent promising alternates for patients with RR-DTC or ATC.

\section{Autophagy in radiosensitization of thyroid cancers}

External beam radiotherapy (EBRT) or intensity-modulated radiotherapy (IMRT) has an established role in treating ATC (Brierley 2011). Although the role of EBRT in locally advanced DTCs is controversial, a recent study elucidated that the addition of EBRT to RAI resulted in good disease control for locally advanced DTCs (Tam et al. 2017). (c) 2019 Society for Endocrinology Published by Bioscientifica Ltd. Printed in Great Britain 
It has been reported that utilization of autophagy inhibitors could increase the radiosensitivity of several types of cancers to radiation therapy (Apel et al. 2008, Liang et al. 2015, Ondrej et al. 2016). However, autophagy activators, rather than inhibitors, may potentially enhance the therapeutic effects of anticancer agents which promote, or at least are compatible with, tumortargeting immune responses (Galluzzi et al. 2017a). Ko et al. also reported that radiotherapy-induced anticancer immune response was autophagy-dependent in the immunocompetent context or, in other words, autophagy conferred immunogenic properties to tumors following radiotherapy (Ko et al. 2014). Consistent with this, inhibition of autophagy, either local or systemic, may trigger detrimental effects in patients with cancer since autophagy is pivotal for establishing $\mathrm{CD}^{+} \mathrm{T}$ cell memory and sustaining the development and survival of lymphocytes (Pua et al. 2007, Puleston et al. 2014). In this setting, further studies are needed to validate whether there is any synergistic benefit by adding modulators of autophagy to radiotherapy in treating patients with advanced thyroid cancers (especially ATC).

\section{Conclusion and future research perspectives}

The tumorigenesis of the thyroid is a complex process, which is regulated by multiple cellular events including activation of oncogenes, inactivation of tumor suppressors and changes in programmed cell death pathways (Yi et al. 2017). The RAS-RAF-MEKERK and PI3K-AKT pathways are the best understood oncogenic cascades orchestrating the proliferation and differentiation of thyroid cancers (Xing 2013, Fagin et al. 2016). In the meantime, both signaling pathways are strongly implicated in the regulation of autophagy activity (Morani et al. 2014, Tesselaar et al. $2017 b$ ). One of the key mechanisms of how autophagy

Table 1 Summary of representative autophagy inhibitors used in preclinical and clinical studies.

\begin{tabular}{|c|c|c|c|c|}
\hline Agent & Target & Tumor types & Status & References \\
\hline Chloroquine (CQ) & Lysosome & $\begin{array}{l}\text { Glioblastoma, brain } \\
\text { Metastases, etc. }\end{array}$ & Clinical trials & Levy et al. (2017) \\
\hline SBI-0206965 & ULK1 & Lung cancer, colorectal cancer & Preclinical & Egan et al. (2015) \\
\hline ULK-101 & ULK1 & Lung cancer & Preclinical & Martin et al. (2018) \\
\hline Hydroxychloroquine (HCQ) & Lysosome & $\begin{array}{l}\text { Colorectal cancer, breast } \\
\text { cancer, pancreatic cancer, etc. }\end{array}$ & Clinical trials & $\begin{array}{l}\text { Levy et al. (2017), } \\
\text { Onorati et al. (2018) }\end{array}$ \\
\hline Quinacrine & Lysosome & Lung cancer, osteosarcoma & Clinical trials & $\begin{array}{l}\text { Wang et al. (2015), } \\
\text { Yan et al. (2018) }\end{array}$ \\
\hline $\begin{array}{l}\text { 3-methyladenine } \\
\text { (3-MA) }\end{array}$ & Beclin/vps34 complex & Prostate cancer, leukemia, etc. & Preclinical & $\begin{array}{l}\text { Lamoureux et al. (2013), } \\
\text { Missiroli et al. (2016) }\end{array}$ \\
\hline Wortmannin & Beclin/vps34 complex & Breast cancer, melanoma, etc. & Preclinical & $\begin{array}{l}\text { Abedin et al. (2007), } \\
\text { Lin et al. (2014) }\end{array}$ \\
\hline Spautin-1 & Beclin/vps34 complex & $\begin{array}{l}\text { Ovarian cancer, breast cancer, } \\
\text { etc. }\end{array}$ & Preclinical & $\begin{array}{l}\text { Liu et al. (2011), Yeo et al. } \\
\text { (2018) }\end{array}$ \\
\hline SAR405 & vps34 & $\begin{array}{l}\text { Renal cancer, head and neck } \\
\text { cancer, etc. }\end{array}$ & Preclinical & $\begin{array}{l}\text { Ronan et al. (2014), } \\
\text { New et al. (2017) }\end{array}$ \\
\hline Autophinib & vps34 & Breast cancer & Preclinical & Robke et al. (2017) \\
\hline PIK-III & vps34 & Pancreatic cancer, etc. & Preclinical & Dowdle et al. (2014) \\
\hline UAMC-2526 & ATG4 & Colorectal cancer & Preclinical & Kurdi et al. (2017) \\
\hline Autophagin-1 & ATG4 & Not reported & Preclinical & Qiu et al. (2016) \\
\hline NSC185058 & ATG4 & Osteosarcoma, glioblastoma & Preclinical & $\begin{array}{l}\text { Akin et al. (2014), } \\
\text { Huang et al. (2017) }\end{array}$ \\
\hline Lys05 & Lysosome & Melanoma, ovarian cancer & Preclinical & $\begin{array}{l}\text { McAfee et al. (2012), } \\
\text { Ma et al. (2014) }\end{array}$ \\
\hline DQ661 & Lysosome & $\begin{array}{l}\text { Melanoma, pancreatic cancer, } \\
\text { and colorectal cancer }\end{array}$ & Preclinical & $\begin{array}{r}\text { Rebecca et al. (2017), } \\
\text { Nicastri et al. (2018) }\end{array}$ \\
\hline ROC-325 & Lysosome & Renal cancer & Preclinical & $\begin{array}{l}\text { Carew et al. (2017), } \\
\text { Carew \& Nawrocki (2017) }\end{array}$ \\
\hline VATG-027 & Lysosome & Melanoma & Preclinical & Goodall et al. (2014) \\
\hline VATG-032 & Lysosome & Melanoma & Preclinical & Goodall et al. (2014) \\
\hline Mefloquine & Lysosome & Breast cancer, etc. & Preclinical & Sharma et al. (2012) \\
\hline Verteporfin & Lysosome & Breast cancer, etc. & Preclinical & Donohue et al. (2011) \\
\hline Bafilomycin A1 (BafA1) & $\begin{array}{l}\text { Lysosome, endoplasmic } \\
\text { reticulum }\end{array}$ & Thyroid cancer, etc. & Preclinical & Mauvezin et al. (2015) \\
\hline
\end{tabular}


promotes the growth and survival of thyroid cancers may lie in its ability to support cellular metabolism and mitochondrial bioenergetics (White et al. 2015, Yu et al. 2018). Mitochondria have long been associated with tumorigenesis by optimizing cancer cell environment and by mediating apoptosis (Wallace 2012). However, the mechanisms by which genetic events, such as BRAFV600E mutation, regulate autophagy-related metabolism are poorly understood in thyroid cancers (Yi et al. 2017). In addition, the cross-talk between autophagy and apoptosis in thyroid cancers still remains to be explored (Nikoletopoulou et al. 2013).

As growth defects from autophagy inhibition of transplanted tumors in immunocompromised mice tend to be less impressive than that observed in autochthonous models (Eng et al. 2016), thyroid cancer models with a thyroid-specific endogenous expression of oncogenes may be better when examining the effects of autophagy activity on thyroid tumorigenesis (Vanden Borre et al. 2014). Although recent findings have indicated the regulatory role of autophagy in the dedifferentiation and concomitant development of RR-DTC, the redifferentiative effect of these autophagy-activating compounds (digitalis-like compounds and cardiac glycosides) in oncogene-induced authenticated murine thyroid cancer models, or in patientderived tumor xenografts (Marlow et al. 2018), is largely unknown. Moreover, assessing the redifferentiative effect of these clinically available agents in a clinical scenario is needed to validate preclinical observations. Apart from these clinically available agents, novel chemical compounds (Galluzzi et al. 2017b, Chiang et al. 2018), or autophagy-inducing peptides (Peraro et al. 2017), could also be used to pharmacologically stimulate autophagy. Since BRAF and MEK inhibitors have been validated as effective in restoring radioiodine incorporation in clinical trials (Ho et al. 2013, Rothenberg et al. 2015, Huillard et al . 2017, Dunn et al. 2018), future studies may also explore if there is a synergistic effect in redifferentiating RR-DTC when a combination of molecularly targeted agent with autophagy activator is applied. Previous seminal studies have demonstrated that ${ }^{124}$ Iodine-NaI PET could detect more lesions than ${ }^{131}$ I single photon emission computed tomography (SPECT), and the former imaging modality also allowed for quantitative dosimetry (Larson et al. 2017). Therefore, future studies may use ${ }^{124}$ Iodine-NaI PET to assess the redifferentiative effect and to optimize subsequent RAI therapy.

Although there are studies reporting autophagic cell death in mediating the anti-thyroid cancer effects of several small-molecular therapeutics (Lin et al. 2010,
Jin et al. 2014, Xiang et al. 2018), future studies are still needed to validate such observations in thyroid cancers. When it comes to inhibiting autophagy for treating thyroid cancers, several promising inhibitors targeting the components of the autophagy pathway have been reported, including ULK1 inhibitors (Egan et al. 2015, Martin et al. 2018), Vps34 inhibitors (Liu et al. 2011, Ronan et al. 2014, Robke et al. 2017), ATG4B inhibitor (Vezenkov et al. 2015), lysosome inhibitors (McAfee et al. 2012, Fu et al. 2014, Kroemer \& Galluzzi 2017, Rebecca et al. 2017) and CQ/HCQ (Table 1). For clinical trials, HCQ is chosen over CQ because of its relatively less toxicity than CQ at peak concentrations (Barnard et al. 2014, Manic et al. 2014). Several clinical trials involving HCQ in combination regimens or as a single-agent trial have been published (Amaravadi et al. 2016). Inhibition of autophagy could overcome vemurafenib resistance in several solid tumors including in thyroid cancers (Mulcahy Levy et al. 2017, Wang et al. 2017). In addition, human tumors generally possess elevated rates of basal autophagy activity, which are further correlated with poor outcome (Amaravadi et al. 2011, Lazova et al. 2012, Kim et al. 2017). Therefore, it is rational to design strategies inhibiting both autophagy and BRAF to enhance the efficacy of BRAF inhibitors and to overcome monotherapy-induced drug resistance in thyroid cancers. One promising future direction is to execute prospective clinical trials to assess the treatment efficacy of highly specific autophagy inhibitors, either alone or in combination with molecularly targeted agents (Mulcahy Levy et al. 2017).

\section{Declaration of interest}

The authors declare that there is no conflict of interest that could be perceived as prejudicing the impartiality of this review.

\section{Funding}

This work was sponsored by the Ph.D. Innovation Fund of Shanghai Jiao Tong University School of Medicine (No. BXJ201736), the Shanghai Key Discipline of Medical Imaging (No. 2017ZZ02005). Weijun Wei was also partially funded by the China Scholarship Council (No. 201706230067).

\section{References}

Abedin MJ, Wang D, McDonnell MA, Lehmann U \& Kelekar A 2007 Autophagy delays apoptotic death in breast cancer cells following DNA damage. Cell Death and Differentiation 14 500-510. (https://doi. org/10.1038/sj.cdd.4402039)

Akin D, Wang SK, Habibzadegah-Tari P, Law B, Ostrov D, Li M, Yin XM, Kim JS, Horenstein N \& Dunn WA Jr 2014 A novel ATG4B antagonist inhibits autophagy and has a negative impact on osteosarcoma tumors. Autophagy 10 2021-2035. (https://doi. org/10.4161/auto.32229)
C) 2019 Society for Endocrinology Published by Bioscientifica Ltd. Printed in Great Britain 
Amaravadi RK, Lippincott-Schwartz J, Yin XM, Weiss WA, Takebe N, Timmer W, DiPaola RS, Lotze MT \& White E 2011 Principles and current strategies for targeting autophagy for cancer treatment. Clinical Cancer Research 17 654-666. (https://doi.org/10.1158/10780432.CCR-10-2634)

Amaravadi R, Kimmelman AC \& White E 2016 Recent insights into the function of autophagy in cancer. Genes and Development 30 1913-1930. (https://doi.org/10.1101/gad.287524.116)

Anania M, Gasparri F, Cetti E, Fraietta I, Todoerti K, Miranda C, Mazzoni M, Re C, Colombo R, Ukmar G, et al. 2015 Identification of thyroid tumor cell vulnerabilities through a siRNA-based functional screening. Oncotarget 6 34629-34648. (https://doi.org/10.18632/ oncotarget.5282)

Anania MC, Cetti E, Lecis D, Todoerti K, Gulino A, Mauro G, Di Marco T, Cleris L, Pagliardini S, Manenti G, et al. 2017 Targeting COPZ1 non-oncogene addiction counteracts the viability of thyroid tumor cells. Cancer Letters 410 201-211. (https://doi.org/10.1016/j. canlet.2017.09.024)

Antico Arciuch VG, Russo MA, Dima M, Kang KS, Dasrath F, Liao XH, Refetoff S, Montagna C \& Di Cristofano A 2011 Thyrocyte-specific inactivation of p53 and Pten results in anaplastic thyroid carcinomas faithfully recapitulating human tumors. Oncotarget 2 1109-1126. (https://doi.org/10.18632/oncotarget.380)

Apel A, Herr I, Schwarz H, Rodemann HP \& Mayer A 2008 Blocked autophagy sensitizes resistant carcinoma cells to radiation therapy. Cancer Research 68 1485-1494. (https://doi.org/10.1158/0008-5472. CAN-07-0562)

Barnard RA, Wittenburg LA, Amaravadi RK, Gustafson DL, Thorburn A \& Thamm DH 2014 Phase I clinical trial and pharmacodynamic evaluation of combination hydroxychloroquine and doxorubicin treatment in pet dogs treated for spontaneously occurring lymphoma. Autophagy 10 1415-1425. (https://doi.org/10.4161/ auto.29165)

Bikas A, Jensen K, Patel A, Costello J Jr, McDaniel D, KluboGwiezdzinska J, Larin O, Hoperia V, Burman KD, Boyle L, et al. 2015 Glucose-deprivation increases thyroid cancer cells sensitivity to metformin. Endocrine-Related Cancer 22 919-932. (https://doi. org/10.1530/ERC-15-0402)

Brierley JD 2011 Update on external beam radiation therapy in thyroid cancer. Journal of Clinical Endocrinology and Metabolism 96 2289-2295. (https://doi.org/10.1210/jc.2011-1109)

Brose MS, Cabanillas ME, Cohen EE, Wirth LJ, Riehl T, Yue H, Sherman SI \& Sherman EJ 2016 Vemurafenib in patients with BRAF(V600E)-positive metastatic or unresectable papillary thyroid cancer refractory to radioactive iodine: a non-randomised, multicentre, open-label, phase 2 trial. Lancet Oncology 17 1272-1282. (https://doi.org/10.1016/S1470-2045(16)30166-8)

Cabanillas ME, McFadden DG \& Durante C 2016 Thyroid cancer. Lancet 388 2783-2795. (https://doi.org/10.1016/S0140-6736(16)30172-6)

Cancer Genome Atlas Research Network 2014 Integrated genomic characterization of papillary thyroid carcinoma. Cell 159 676-690. (https://doi.org/10.1016/j.cell.2014.09.050)

Carew JS \& Nawrocki ST 2017 Drain the lysosome: development of the novel orally available autophagy inhibitor ROC-325. Autophagy $\mathbf{1 3}$ 765-766. (https://doi.org/10.1080/15548627.2017.1280222)

Carew JS, Espitia CM, Zhao W, Han Y, Visconte V, Phillips J \& Nawrocki ST 2017 Disruption of autophagic degradation with ROC325 antagonizes renal cell carcinoma pathogenesis. Clinical Cancer Research 23 2869-2879. (https://doi.org/10.1158/1078-0432.CCR-161742)

Chakravarty D, Santos E, Ryder M, Knauf JA, Liao XH, West BL, Bollag G, Kolesnick R, Thin TH, Rosen N, et al. 2011 Smallmolecule MAPK inhibitors restore radioiodine incorporation in mouse thyroid cancers with conditional BRAF activation. Journal of Clinical Investigation 121 4700-4711. (https://doi.org/10.1172/ JCI46382)
Champa D, Orlacchio A, Patel B, Ranieri M, Shemetov AA, Verkhusha VV, Cuervo AM \& Di Cristofano A 2016 Obatoclax kills anaplastic thyroid cancer cells by inducing lysosome neutralization and necrosis. Oncotarget 7 34453-34471. (https://doi.org/10.18632/ oncotarget.9121)

Chen X, Mitsutake N, LaPerle K, Akeno N, Zanzonico P, Longo VA, Mitsutake S, Kimura ET, Geiger H, Santos E, et al. 2009 Endogenous expression of Hras(G12V) induces developmental defects and neoplasms with copy number imbalances of the oncogene. PNAS 106 7979-7984. (https://doi.org/10.1073/pnas.0900343106)

Chen W, Zheng R, Baade PD, Zhang S, Zeng H, Bray F, Jemal A, Yu XQ \& He J 2016 Cancer statistics in China, 2015. CA: A Cancer Journal for Clinicians 66 115-132. (https://doi.org/10.3322/caac.21338)

Chi HC, Chen SL, Lin SL, Tsai CY, Chuang WY, Lin YH, Huang YH, Tsai MM, Yeh CT \& Lin KH 2017 Thyroid hormone protects hepatocytes from $\mathrm{HBx}$-induced carcinogenesis by enhancing mitochondrial turnover. Oncogene 36 5274-5284. (https://doi. org/10.1038/onc.2017.136)

Chiang WC, Wei Y, Kuo YC, Wei S, Zhou A, Zou Z, Yehl J, Ranaghan MJ, Skepner A, Bittker JA, et al. 2018 High-Throughput Screens To identify autophagy inducers that function by disrupting beclin $1 /$ Bcl-2 binding. ACS Chemical Biology 13 2247-2260. (https://doi. org/10.1021/acschembio.8b00421)

Claerhout S, Dutta B, Bossuyt W, Zhang F, Nguyen-Charles C, Dennison JB, Yu Q, Yu S, Balazsi G, Lu Y, et al. 2012 Abortive autophagy induces endoplasmic reticulum stress and cell death in cancer cells. PLoS One 7 e39400. (https://doi.org/10.1371/journal. pone.0039400)

Dadu R, Shah K, Busaidy NL, Waguespack SG, Habra MA, Ying AK, Hu MI, Bassett R, Jimenez C, Sherman SI, et al. 2015 Efficacy and tolerability of vemurafenib in patients with BRAF(V600E) -positive papillary thyroid cancer: M.D. Anderson Cancer Center off label experience. Journal of Clinical Endocrinology and Metabolism 100 E77E81. (https://doi.org/10.1210/jc.2014-2246)

Donohue E, Tovey A, Vogl AW, Arns S, Sternberg E, Young RN \& Roberge M 2011 Inhibition of autophagosome formation by the benzoporphyrin derivative verteporfin. Journal of Biological Chemistry 286 7290-7300. (https://doi.org/10.1074/jbc.M110.139915)

Dowdle WE, Nyfeler B, Nagel J, Elling RA, Liu S, Triantafellow E, Menon S, Wang Z, Honda A, Pardee G, et al. 2014 Selective VPS34 inhibitor blocks autophagy and uncovers a role for NCOA4 in ferritin degradation and iron homeostasis in vivo. Nature Cell Biology 16 1069-1079. (https://doi.org/10.1038/ncb3053)

Dunn LA, Sherman EJ, Baxi SS, Tchekmedyian V, Grewal RK, Larson SM, Pentlow KS, Haque S, Tuttle RM, Sabra MM, et al. 2018 Vemurafenib redifferentiation of BRAF mutant, RAI-refractory thyroid cancers. Journal of Clinical Endocrinology and Metabolism [epub]. (https://doi. org/10.1210/jc.2018-01478)

Egan DF, Chun MG, Vamos M, Zou H, Rong J, Miller CJ, Lou HJ, Raveendra-Panickar D, Yang CC, Sheffler DJ, et al. 2015 Small molecule inhibition of the autophagy kinase ULK1 and identification of ULK1 substrates. Molecular Cell 59 285-297. (https://doi.org/10.1016/j.molcel.2015.05.031)

ElMokh O, Taelmann V, Radojewski P, Roelli MA, Stooss A, Dumont RA, Dettmer M, Phillips W, Walter MA \& Charles RR 2018 MEK inhibition induces therapeutic iodine uptake in a murine model of anaplastic thyroid cancer. Journal of Nuclear Medicine [epub]. (https:// doi.org/10.2967/jnumed.118.216721)

Eng CH, Wang Z, Tkach D, Toral-Barza L, Ugwonali S, Liu S, Fitzgerald SL, George E, Frias E, Cochran N, et al. 2016 Macroautophagy is dispensable for growth of KRAS mutant tumors and chloroquine efficacy. PNAS 113 182-187. (https://doi. org/10.1073/pnas.1515617113)

Fagin JA \& Wells SA Jr 2016 Biologic and Clinical Perspectives on Thyroid Cancer. New England Journal of Medicine 375 1054-1067. (https://doi.org/10.1056/NEJMra1501993) https://erc.bioscientifica.com

https://doi.org/10.1530/ERC-18-0502
(C) 2019 Society for Endocrinology Published by Bioscientifica Ltd. Printed in Great Britain 
Fan D, Liu SY, van Hasselt CA, Vlantis AC, Ng EK, Zhang H, Dong Y, $\mathrm{Ng}$ SK, Chu R, Chan AB, et al. 2015 Estrogen receptor alpha induces prosurvival autophagy in papillary thyroid cancer via stimulating reactive oxygen species and extracellular signal regulated kinases. Journal of Clinical Endocrinology and Metabolism 100 E561-E571. (https://doi.org/10.1210/jc.2014-3257)

Feng H, Cheng X, Kuang J, Chen L, Yuen S, Shi M, Liang J, Shen B, Jin Z, Yan J, et al. 2018 Apatinib-induced protective autophagy and apoptosis through the AKT-mTOR pathway in anaplastic thyroid cancer. Cell Death and Disease 9 1030. (https://doi.org/10.1038/ s41419-018-1054-3)

Franco AT, Malaguarnera R, Refetoff S, Liao XH, Lundsmith E, Kimura S, Pritchard C, Marais R, Davies TF, Weinstein LS, et al. 2011 Thyrotrophin receptor signaling dependence of Braf-induced thyroid tumor initiation in mice. PNAS 108 1615-1620. (https://doi. org/10.1073/pnas.1015557108)

Fu D, Zhou J, Zhu WS, Manley PW, Wang YK, Hood T, Wylie A \& Xie XS 2014 Imaging the intracellular distribution of tyrosine kinase inhibitors in living cells with quantitative hyperspectral stimulated Raman scattering. Nature Chemistry 6 614-622. (https://doi. org/10.1038/nchem.1961)

Galluzzi L, Bravo-San Pedro JM, Demaria S, Formenti SC \& Kroemer G 2017 a Activating autophagy to potentiate immunogenic chemotherapy and radiation therapy. Nature Reviews: Clinical Oncology 14 247-258. (https://doi.org/10.1038/nrclinonc.2016.183)

Galluzzi L, Bravo-San Pedro JM, Levine B, Green DR \& Kroemer G 2017b Pharmacological modulation of autophagy: therapeutic potential and persisting obstacles. Nature Reviews: Drug Discovery 16 487-511. (https://doi.org/10.1038/nrd.2017.22)

Gimm O, Armanios M, Dziema H, Neumann HP \& Eng C 2000 Somatic and occult germ-line mutations in SDHD, a mitochondrial complex II gene, in nonfamilial pheochromocytoma. Cancer Research 60 6822-6825.

Goodall ML, Wang T, Martin KR, Kortus MG, Kauffman AL, Trent JM, Gately S \& MacKeigan JP 2014 Development of potent autophagy inhibitors that sensitize oncogenic BRAF V600E mutant melanoma tumor cells to vemurafenib. Autophagy 10 1120-1136. (https://doi. org/10.4161/auto.28594)

Grenier K, McLelland GL \& Fon EA 2013 Parkin- and PINK1-dependent mitophagy in neurons: will the real pathway please stand up? Frontiers in Neurology 4 100. (https://doi.org/10.3389/ fneur.2013.00100)

Gugnoni M, Sancisi V, Gandolfi G, Manzotti G, Ragazzi M, Giordano D, Tamagnini I, Tigano M, Frasoldati A, Piana S, et al. 2017 Cadherin-6 promotes EMT and cancer metastasis by restraining autophagy. Oncogene 36 667-677. (https://doi.org/10.1038/onc.2016.237)

Guigon CJ, Zhao L, Willingham MC \& Cheng SY 2009 PTEN deficiency accelerates tumour progression in a mouse model of thyroid cancer. Oncogene 28 509-517. (https://doi.org/10.1038/onc.2008.407)

Guo JY, Karsli-Uzunbas G, Mathew R, Aisner SC, Kamphorst JJ, Strohecker AM, Chen G, Price S, Lu W, Teng X, et al. 2013 Autophagy suppresses progression of K-ras-induced lung tumors to oncocytomas and maintains lipid homeostasis. Genes and Development 27 1447-1461. (https://doi.org/10.1101/gad.219642.113)

Hanna GJ, Busaidy NL, Chau NG, Wirth LJ, Barletta JA, Calles A, Haddad RI, Kraft S, Cabanillas ME, Rabinowits G, et al. 2018 Genomic correlates of response to everolimus in aggressive radioiodine-refractory thyroid cancer: a phase II study. Clinical Cancer Research 24 1546-1553. (https://doi.org/10.1158/1078-0432. CCR-17-2297)

Hardin H, Zhang R, Helein H, Buehler D, Guo Z \& Lloyd RV 2017 The evolving concept of cancer stem-like cells in thyroid cancer and other solid tumors. Laboratory Investigation 97 1142-1151. (https:// doi.org/10.1038/labinvest.2017.41)

Hardy RG, Vicente-Duenas C, Gonzalez-Herrero I, Anderson C, Flores T, Hughes S, Tselepis C, Ross JA \& Sanchez-Garcia I 2007 Snail family transcription factors are implicated in thyroid carcinogenesis. American Journal of Pathology 171 1037-1046. (https://doi. org/10.2353/ajpath.2007.061211)

He Q, Liu W, Sha S, Fan S, Yu Y, Chen L \& Dong M 2018 Adenosine 5 '-monophosphate-activated protein kinase-dependent mTOR pathway is involved in flavokawain B-induced autophagy in thyroid cancer cells. Cancer Science 109 2576-2589. (https://doi.org/10.1111/ cas.13699)

Ho AL, Grewal RK, Leboeuf R, Sherman EJ, Pfister DG, Deandreis D, Pentlow KS, Zanzonico PB, Haque S, Gavane S, et al. 2013 Selumetinib-enhanced radioiodine uptake in advanced thyroid cancer. New England Journal of Medicine 368 623-632. (https://doi. org/10.1056/NEJMoa1209288)

Huang T, Kim CK, Alvarez AA, Pangeni RP, Wan X, Song X, Shi T, Yang Y, Sastry N, Horbinski CM, et al. 2017 MST4 phosphorylation of ATG4B regulates autophagic activity, tumorigenicity, and radioresistance in glioblastoma. Cancer Cell 32 840-855.e8. (https:// doi.org/10.1016/j.ccell.2017.11.005)

Huijbers A, Plantinga TS, Joosten LA, Aben KK, Gudmundsson J, den Heijer M, Kiemeney LA, Netea MG, Hermus AR \& Netea-Maier RT 2012 The effect of the ATG16L1 Thr300Ala polymorphism on susceptibility and outcome of patients with epithelial cell-derived thyroid carcinoma. Endocrine-Related Cancer 19 L15-L18. (https://doi. org/10.1530/ERC-11-0302)

Huillard O, Tenenbaum F, Clerc J, Goldwasser F \& Groussin L 2017 Restoring radioiodine uptake in BRAF V600E-mutated papillary thyroid cancer. Journal of the Endocrine Society 1 285-287. (https:// doi.org/10.1210/js.2016-1114)

Iyer PC, Dadu R, Ferrarotto R, Busaidy NL, Habra MA, Zafereo M, Gross N, Hess KR, Gule-Monroe M, Williams MD, et al. 2018 Realworld experience with targeted therapy for the treatment of anaplastic thyroid carcinoma. Thyroid 28 79-87. (https://doi. org/10.1089/thy.2017.0285)

Jin SM, Jang HW, Sohn SY, Kim NK, Joung JY, Cho YY, Kim SW \& Chung JH 2014 Role of autophagy in the resistance to tumour necrosis factor-related apoptosis-inducing ligand-induced apoptosis in papillary and anaplastic thyroid cancer cells. Endocrine $\mathbf{4 5}$ 256-262. (https://doi.org/10.1007/s12020-013-9997-8)

Karsli-Uzunbas G, Guo JY, Price S, Teng X, Laddha SV, Khor S, Kalaany NY, Jacks T, Chan CS, Rabinowitz JD, et al. 2014 Autophagy is required for glucose homeostasis and lung tumor maintenance. Cancer Discovery 4 914-927. (https://doi.org/10.1158/2159-8290. CD-14-0363)

Keutgen XM, Sadowski SM \& Kebebew E 2015 Management of anaplastic thyroid cancer. Gland Surgery 4 44-51. (https://doi. org/10.3978/j.issn.2227-684X.2014.12.02)

Kim KB, Cabanillas ME, Lazar AJ, Williams MD, Sanders DL, Ilagan JL, Nolop K, Lee RJ \& Sherman SI 2013 Clinical responses to vemurafenib in patients with metastatic papillary thyroid cancer harboring BRAF(V600E) mutation. Thyroid 23 1277-1283. (https:// doi.org/10.1089/thy.2013.0057)

Kim HM, Kim ES \& Koo JS 2017 Expression of autophagy-related proteins in different types of thyroid cancer. International Journal of Molecular Sciences 18 E540. (https://doi.org/10.3390/ijms18030540)

Klionsky DJ, Abdelmohsen K, Abe A, Abedin MJ, Abeliovich H, Acevedo Arozena A, Adachi H, Adams CM, Adams PD, Adeli K, et al. 2016 Guidelines for the use and interpretation of assays for monitoring autophagy (3rd edition). Autophagy 12 1-222. (https://doi.org/10.108 0/15548627.2015.1100356)

Ko A, Kanehisa A, Martins I, Senovilla L, Chargari C, Dugue D, Marino G, Kepp O, Michaud M, Perfettini JL, et al. 2014 Autophagy inhibition radiosensitizes in vitro, yet reduces radioresponses in vivo due to deficient immunogenic signalling. Cell Death and Differentiation 21 92-99. (https://doi.org/10.1038/cdd.2013.124)

Kreissl MC, Janssen MJR \& Nagarajah J 2019 Current treatment strategies in metastasized differentiated thyroid cancer. Journal of https://erc.bioscientifica.com

https://doi.org/10.1530/ERC-18-0502 (c) 2019 Society for Endocrinology Published by Bioscientifica Ltd. Printed in Great Britain 
Nuclear Medicine 60 9-15. (https://doi.org/10.2967/ jnumed.117.190819)

Kroemer G \& Galluzzi L 2017 Lysosome-targeting agents in cancer therapy. Oncotarget 8 112168-112169. (https://doi.org/10.18632/ oncotarget.21451)

Kurdi A, Cleenewerck M, Vangestel C, Lyssens S, Declercq W, Timmermans JP, Stroobants S, Augustyns K, De Meyer GRY, Van Der Veken P, et al. 2017 ATG4B inhibitors with a benzotropolone core structure block autophagy and augment efficiency of chemotherapy in mice. Biochemical Pharmacology 138 150-162. (https://doi. org/10.1016/j.bcp.2017.06.119)

Lamoureux F, Thomas C, Crafter C, Kumano M, Zhang F, Davies BR, Gleave ME \& Zoubeidi A 2013 Blocked autophagy using lysosomotropic agents sensitizes resistant prostate tumor cells to the novel Akt inhibitor AZD5363. Clinical Cancer Research 19 833-844. (https://doi.org/10.1158/1078-0432.CCR-12-3114)

Landa I, Ibrahimpasic T, Boucai L, Sinha R, Knauf JA, Shah RH, Dogan S, Ricarte-Filho JC, Krishnamoorthy GP, Xu B, et al. 2016 Genomic and transcriptomic hallmarks of poorly differentiated and anaplastic thyroid cancers. Journal of Clinical Investigation 126 1052-1066. (https://doi.org/10.1172/JCI85271)

Larson SM, Osborne JR, Grewal RK \& Tuttle RM 2017 Redifferentiating thyroid cancer: selumetinib-enhanced radioiodine uptake in thyroid cancer. Molecular Imaging and Radionuclide Therapy 26 80-86. (https:// doi.org/10.4274/2017.26.suppl.09)

Lazova R, Camp RL, Klump V, Siddiqui SF, Amaravadi RK \& Pawelek JM 2012 Punctate LC3B expression is a common feature of solid tumors and associated with proliferation, metastasis, and poor outcome. Clinical Cancer Research 18 370-379. (https://doi.org/10.1158/10780432.CCR-11-1282)

Lee J, Ham S, Lee MH, Kim SJ, Park JH, Lee SE, Chang JY, Joung KH, Kim TY, Kim JM, et al. 2015 Dysregulation of Parkin-mediated mitophagy in thyroid Hurthle cell tumors. Carcinogenesis 36 1407-1418. (https://doi.org/10.1093/carcin/bgv122)

Lee J, Yi S, Kang YE, Chang JY, Kim JT, Sul HJ, Kim JO, Kim JM, Kim J, Porcelli AM, et al. 2016 Defective ciliogenesis in thyroid Hurthle cell tumors is associated with increased autophagy. Oncotarget 7 79117-79130. (https://doi.org/10.18632/oncotarget.12997)

Levy JMM, Towers CG \& Thorburn A 2017 Targeting autophagy in cancer. Nature Reviews: Cancer 17 528-542. (https://doi.org/10.1038/ nrc.2017.53)

Liang DH, El-Zein R \& Dave B 2015 Autophagy inhibition to increase radiosensitization in breast cancer. Journal of Nuclear Medicine and Radiation Therapy 6 254. (https://doi.org/10.4172/21559619.1000254)

Lin CI, Whang EE, Donner DB, Du J, Lorch J, He F, Jiang X, Price BD, Moore FD Jr \& Ruan DT 2010 Autophagy induction with RAD001 enhances chemosensitivity and radiosensitivity through Met inhibition in papillary thyroid cancer. Molecular Cancer Research $\mathbf{8}$ 1217-1226. (https://doi.org/10.1158/1541-7786.MCR-10-0162)

Lin CI, Whang EE, Lorch JH \& Ruan DT 2012 Autophagic activation potentiates the antiproliferative effects of tyrosine kinase inhibitors in medullary thyroid cancer. Surgery 152 1142-1149. (https://doi. org/10.1016/j.surg.2012.08.016)

Lin J, Huang Z, Wu H, Zhou W, Jin P, Wei P, Zhang Y, Zheng F, Zhang J, $\mathrm{Xu}$ J, et al. 2014 Inhibition of autophagy enhances the anticancer activity of silver nanoparticles. Autophagy 10 2006-2020. (https:// doi.org/10.4161/auto.36293)

Lin Y, Wang C, Gao W, Cui R \& Liang J 2017 Overwhelming rapid metabolic and structural response to apatinib in radioiodine refractory differentiated thyroid cancer. Oncotarget 8 42252-42261. (https://doi.org/10.18632/oncotarget.15036)

Liu J, Xia H, Kim M, Xu L, Li Y, Zhang L, Cai Y, Norberg HV, Zhang T, Furuya T, et al. 2011 Beclin1 controls the levels of p53 by regulating the deubiquitination activity of USP10 and USP13. Cell 147 223-234. (https://doi.org/10.1016/j.cell.2011.08.037)
Long HL, Zhang FF, Wang HL, Yang WS, Hou HT, Yu JK \& Liu B 2018 Mulberry anthocyanins improves thyroid cancer progression mainly by inducing apoptosis and autophagy cell death. Kaohsiung Journal of Medical Sciences 34 255-262. (https://doi.org/10.1016/j. kjms.2017.11.004)

Lu CH, Chen SH, Chang YS, Liu YW, Wu JY, Lim YP, Yu HI \& Lee YR 2017 Honokiol, a potential therapeutic agent, induces cell cycle arrest and program cell death in vitro and in vivo in human thyroid cancer cells. Pharmacological Research 115 288-298. (https://doi. org/10.1016/j.phrs.2016.11.038)

Ma XH, Piao SF, Dey S, McAfee Q, Karakousis G, Villanueva J, Hart LS, Levi S, Hu J, Zhang G, et al. 2014 Targeting ER stress-induced autophagy overcomes BRAF inhibitor resistance in melanoma. Journal of Clinical Investigation 124 1406-1417. (https://doi. org/10.1172/JCI70454)

Manic G, Obrist F, Kroemer G, Vitale I \& Galluzzi L 2014 Chloroquine and hydroxychloroquine for cancer therapy. Molecular and Cellular Oncology 1 e29911. (https://doi.org/10.4161/mco.29911)

Manole D, Schildknecht B, Gosnell B, Adams E \& Derwahl M 2001 Estrogen promotes growth of human thyroid tumor cells by different molecular mechanisms. Journal of Clinical Endocrinology and Metabolism 86 1072-1077. (https://doi.org/10.1210/ jcem.86.3.7283)

Marcucci F, Ghezzi P \& Rumio C 2017 The role of autophagy in the cross-talk between epithelial-mesenchymal transitioned tumor cells and cancer stem-like cells. Molecular Cancer 16 3. (https://doi. org/10.1186/s12943-016-0573-8)

Marlow LA, Rohl SD, Miller JL, Knauf JA, Fagin JA, Ryder M, Milosevic D, Netzel BC, Grebe SK, Reddi HV, et al. 2018 Methodology, criteria, and characterization of patient-matched thyroid cell lines and patient-derived tumor xenografts. Journal of Clinical Endocrinology and Metabolism 103 3169-3182. (https://doi. org/10.1210/jc.2017-01845)

Martin KR, Celano SL, Solitro AR, Gunaydin H, Scott M, O'Hagan RC, Shumway SD, Fuller P \& MacKeigan JP 2018 A potent and selective ULK1 inhibitor suppresses autophagy and sensitizes cancer cells to nutrient stress. iScience 8 74-84. (https://doi.org/10.1016/j. isci.2018.09.012)

Mauvezin C, Nagy P, Juhasz G \& Neufeld TP 2015 Autophagosomelysosome fusion is independent of V-ATPase-mediated acidification. Nature Communications 6 7007. (https://doi.org/10.1038/ ncomms8007)

Maximo V, Lima J, Prazeres H, Soares P \& Sobrinho-Simoes M 2012 The biology and the genetics of Hurthle cell tumors of the thyroid. Endocrine-Related Cancer 19 R131-R147. (https://doi.org/10.1530/ ERC-11-0354)

McAfee Q, Zhang Z, Samanta A, Levi SM, Ma XH, Piao S, Lynch JP, Uehara T, Sepulveda AR, Davis LE, et al. 2012 Autophagy inhibitor Lys05 has single-agent antitumor activity and reproduces the phenotype of a genetic autophagy deficiency. PNAS 109 8253-8258. (https://doi.org/10.1073/pnas.1118193109)

McFadden DG, Vernon A, Santiago PM, Martinez-McFaline R, Bhutkar A, Crowley DM, McMahon M, Sadow PM \& Jacks T 2014 p53 constrains progression to anaplastic thyroid carcinoma in a Brafmutant mouse model of papillary thyroid cancer. PNAS 111 E1600-E1609. (https://doi.org/10.1073/pnas.1404357111)

Missiroli S, Bonora M, Patergnani S, Poletti F, Perrone M, Gafa R, Magri E, Raimondi A, Lanza G, Tacchetti C, et al. 2016 PML at Mitochondria-associated membranes is critical for the repression of autophagy and cancer development. Cell Reports 16 2415-2427. (https://doi.org/10.1016/j.celrep.2016.07.082)

Molinaro E, Romei C, Biagini A, Sabini E, Agate L, Mazzeo S, Materazzi G, Sellari-Franceschini S, Ribechini A, Torregrossa L, et al. 2017 Anaplastic thyroid carcinoma: from clinicopathology to genetics and advanced therapies. Nature Reviews: Endocrinology 13 644-660. (https://doi.org/10.1038/nrendo.2017.76) https://erc.bioscientifica.com

https://doi.org/10.1530/ERC-18-0502 (c) 2019 Society for Endocrinology Published by Bioscientifica Ltd. Printed in Great Britain 
Morani F, Titone R, Pagano L, Galetto A, Alabiso O, Aimaretti G \& Isidoro C 2014 Autophagy and thyroid carcinogenesis: genetic and epigenetic links. Endocrine-Related Cancer 21 R13-R29. (https://doi. org/10.1530/ERC-13-0271)

Mulcahy Levy JM, Zahedi S, Griesinger AM, Morin A, Davies KD, Aisner DL, Kleinschmidt-DeMasters BK, Fitzwalter BE, Goodall ML, Thorburn J, et al. 2017 Autophagy inhibition overcomes multiple mechanisms of resistance to BRAF inhibition in brain tumors. eLife $\mathbf{6}$ e19671. (https://doi.org/10.7554/eLife.19671)

Netea-Maier RT, Kluck V, Plantinga TS \& Smit JW 2015 Autophagy in thyroid cancer: present knowledge and future perspectives. Frontiers in Endocrinology 6 22. (https://doi.org/10.3389/fendo.2015.00022)

New J, Arnold L, Ananth M, Alvi S, Thornton M, Werner L, Tawfik O, Dai H, Shnayder Y, Kakarala K, et al. 2017 Secretory autophagy in cancer-associated fibroblasts promotes head and neck cancer progression and offers a novel therapeutic target. Cancer Research $\mathbf{7 7}$ 6679-6691. (https://doi.org/10.1158/0008-5472.CAN-17-1077)

Nicastri MC, Rebecca VW, Amaravadi RK \& Winkler JD 2018 Dimeric quinacrines as chemical tools to identify PPT1, a new regulator of autophagy in cancer cells. Molecular and Cellular Oncology 5 e1395504. (https://doi.org/10.1080/23723556.2017.1395504)

Nikoletopoulou V, Markaki M, Palikaras K \& Tavernarakis N 2013 Crosstalk between apoptosis, necrosis and autophagy. Biochimica et Biophysica Acta 1833 3448-3459. (https://doi.org/10.1016/j. bbamcr.2013.06.001)

Ondrej M, Cechakova L, Durisova K, Pejchal J \& Tichy A 2016 To live or let die: unclear task of autophagy in the radiosensitization battle. Radiotherapy and Oncology 119 265-275. (https://doi.org/10.1016/j. radonc.2016.02.028)

Onorati AV, Dyczynski M, Ojha R \& Amaravadi RK 2018 Targeting autophagy in cancer. Cancer 124 3307-3318. (https://doi. org/10.1002/cncr.31335)

Pampliega O, Orhon I, Patel B, Sridhar S, Diaz-Carretero A, Beau I, Codogno P, Satir BH, Satir P \& Cuervo AM 2013 Functional interaction between autophagy and ciliogenesis. Nature $\mathbf{5 0 2}$ 194-200. (https://doi.org/10.1038/nature12639)

Park J, Lee SB, Lee S, Kim Y, Song S, Kim S, Bae E, Kim J, Shong M, Kim JM, et al. 2006 Mitochondrial dysfunction in Drosophila PINK1 mutants is complemented by parkin. Nature 441 1157-1161. (https://doi.org/10.1038/nature04788)

Peraro L, Zou Z, Makwana KM, Cummings AE, Ball HL, Yu H, Lin YS, Levine B \& Kritzer JA 2017 Diversity-oriented stapling yields intrinsically cell-penetrant inducers of autophagy. Journal of the American Chemical Society 139 7792-7802. (https://doi.org/10.1021/ jacs.7b01698)

Plantinga TS, van de Vosse E, Huijbers A, Netea MG, Joosten LA, Smit JW \& Netea-Maier RT 2014 Role of genetic variants of autophagy genes in susceptibility for non-medullary thyroid cancer and patients outcome. PLoS One 9 e94086. (https://doi.org/10.1371/ journal.pone.0094086)

Plantinga TS, Tesselaar MH, Morreau H, Corssmit EP, Willemsen BK, Kusters B, van Engen-van Grunsven AC, Smit JW \& Netea-Maier RT 2016 Autophagy activity is associated with membranous sodium iodide symporter expression and clinical response to radioiodine therapy in non-medullary thyroid cancer. Autophagy 12 1195-1205. (https://doi.org/10.1080/15548627.2016.1174802)

Plews RL, Mohd Yusof A, Wang C, Saji M, Zhang X, Chen CS, Ringel MD \& Phay JE 2015 A novel dual AMPK activator/mTOR inhibitor inhibits thyroid cancer cell growth. Journal of Clinical Endocrinology and Metabolism 100 E748-E756. (https://doi. org/10.1210/jc.2014-1777)

Prasad R \& Katiyar SK 2016 Honokiol, an active compound of magnolia plant, inhibits growth, and progression of cancers of different organs. Advances in Experimental Medicine and Biology 928 245-265. (https://doi.org/10.1007/978-3-319-41334-1_11)
Prassas I \& Diamandis EP 2008 Novel therapeutic applications of cardiac glycosides. Nature Reviews: Drug Discovery 7 926-935. (https://doi. org/10.1038/nrd2682)

Pua HH, Dzhagalov I, Chuck M, Mizushima N \& He YW 2007 A critical role for the autophagy gene Atg5 in T cell survival and proliferation. Journal of Experimental Medicine 204 25-31. (https://doi.org/10.1084/ jem.20061303)

Puleston DJ, Zhang H, Powell TJ, Lipina E, Sims S, Panse I, Watson AS, Cerundolo V, Townsend AR, Klenerman P, et al. 2014 Autophagy is a critical regulator of memory CD8(+) T cell formation. eLife $\mathbf{3}$ e03706. (https://doi.org/10.7554/eLife.03706)

Qin Y, Sun W, Zhang H, Zhang P, Wang Z, Dong W, He L, Zhang T, Shao L, Zhang W, et al. 2018 LncRNA GAS8-AS1 inhibits cell proliferation through ATG5-mediated autophagy in papillary thyroid cancer. Endocrine 59 555-564. (https://doi.org/10.1007/s12020-0171520-1)

Qiu Z, Kuhn B, Aebi J, Lin X, Ding H, Zhou Z, Xu Z, Xu D, Han L, Liu C, et al. 2016 Discovery of fluoromethylketone-based peptidomimetics as covalent ATG4B (autophagin-1) inhibitors. ACS Medicinal Chemistry Letters 7 802-806. (https://doi.org/10.1021/ acsmedchemlett.6b00208)

Ragazzi M, Ciarrocchi A, Sancisi V, Gandolfi G, Bisagni A \& Piana S 2014 Update on anaplastic thyroid carcinoma: morphological, molecular, and genetic features of the most aggressive thyroid cancer. International Journal of Endocrinology 2014 790834. (https://doi. org/10.1155/2014/790834)

Razi M, Chan EY \& Tooze SA 2009 Early endosomes and endosomal coatomer are required for autophagy. Journal of Cell Biology $\mathbf{1 8 5}$ 305-321. (https://doi.org/10.1083/jcb.200810098)

Rebecca VW, Nicastri MC, McLaughlin N, Fennelly C, McAfee Q, Ronghe A, Nofal M, Lim CY, Witze E, Chude CI, et al. 2017 A unified approach to targeting the lysosome's degradative and growth signaling roles. Cancer Discovery 7 1266-1283. (https://doi. org/10.1158/2159-8290.CD-17-0741)

Robke L, Laraia L, Carnero Corrales MA, Konstantinidis G, Muroi M, Richters A, Winzker M, Engbring T, Tomassi S, Watanabe N, et al. 2017 Phenotypic identification of a novel autophagy inhibitor chemotype targeting lipid kinase VPS34. Angewandte Chemie 56 8153-8157. (https://doi.org/10.1002/anie.201703738)

Ronan B, Flamand O, Vescovi L, Dureuil C, Durand L, Fassy F, Bachelot MF, Lamberton A, Mathieu M, Bertrand T, et al. 2014 A highly potent and selective Vps34 inhibitor alters vesicle trafficking and autophagy. Nature Chemical Biology 10 1013-1019. (https://doi. org/10.1038/nchembio.1681)

Rothenberg SM, McFadden DG, Palmer EL, Daniels GH \& Wirth LJ 2015 Redifferentiation of iodine-refractory BRAF V600E-mutant metastatic papillary thyroid cancer with dabrafenib. Clinical Cancer Research 21 1028-1035. (https://doi.org/10.1158/1078-0432.CCR-14-2915)

Sancisi V, Gandolfi G, Ragazzi M, Nicoli D, Tamagnini I, Piana S \& Ciarrocchi A 2013 Cadherin 6 is a new RUNX2 target in TGF-beta signalling pathway. PLoS One 8 e75489. (https://doi.org/10.1371/ journal.pone.0075489)

Sandulache VC, Williams MD, Lai SY, Lu C, William WN, Busaidy NL, Cote GJ, Singh RR, Luthra R \& Cabanillas ME 2017 Real-time genomic characterization utilizing circulating cell-free DNA in patients with anaplastic thyroid carcinoma. Thyroid 27 81-87. (https://doi.org/10.1089/thy.2016.0076)

Satir BH \& Pampliega O 2016 Methods to study interactions between ciliogenesis and autophagy. Methods in Molecular Biology 1454 53-67. (https://doi.org/10.1007/978-1-4939-3789-9_4)

Schweppe RE, Klopper JP, Korch C, Pugazhenthi U, Benezra M, Knauf JA, Fagin JA, Marlow LA, Copland JA, Smallridge RC, et al. 2008 Deoxyribonucleic acid profiling analysis of 40 human thyroid cancer cell lines reveals cross-contamination resulting in cell line redundancy and misidentification. Journal of Clinical Endocrinology https://erc bioscientifica.com

https://doi.org/10.1530/ERC-18-0502
(C) 2019 Society for Endocrinology Published by Bioscientifica Ltd. Printed in Great Britain 
and Metabolism 93 4331-4341. (https://doi.org/10.1210/jc.20081102)

Sharma N, Thomas S, Golden EB, Hofman FM, Chen TC, Petasis NA, Schonthal AH \& Louie SG 2012 Inhibition of autophagy and induction of breast cancer cell death by mefloquine, an antimalarial agent. Cancer Letters 326 143-154. (https://doi.org/10.1016/j. canlet.2012.07.029)

Shen CT, Qiu ZL \& Luo QY 2014 Sorafenib in the treatment of radioiodine-refractory differentiated thyroid cancer: a meta-analysis. Endocrine-Related Cancer 21 253-261. (https://doi.org/10.1530/ERC13-0438)

Shtutman M, Baig M, Levina E, Hurteau G, Lim CU, Broude E, Nikiforov M, Harkins TT, Carmack CS, Ding Y, et al. 2011 Tumorspecific silencing of COPZ2 gene encoding coatomer protein complex subunit zeta 2 renders tumor cells dependent on its paralogous gene COPZ1. PNAS 108 12449-12454. (https://doi. org/10.1073/pnas.1103842108)

Sinha RA, Singh BK, Zhou J, Wu Y, Farah BL, Ohba K, Lesmana R, Gooding J, Bay BH \& Yen PM 2015 Thyroid hormone induction of mitochondrial activity is coupled to mitophagy via ROS-AMPK-ULK1 signaling. Autophagy 11 1341-1357. (https://doi.org/10.1080/155486 27.2015.1061849)

Song HJ, Qiu ZL, Shen CT, Wei WJ \& Luo QY 2015 Pulmonary metastases in differentiated thyroid cancer: efficacy of radioiodine therapy and prognostic factors. European Journal of Endocrinology 173 399-408. (https://doi.org/10.1530/EJE-15-0296)

Strohecker AM, Guo JY, Karsli-Uzunbas G, Price SM, Chen GJ, Mathew R, McMahon M \& White E 2013 Autophagy sustains mitochondrial glutamine metabolism and growth of BrafV600Edriven lung tumors. Cancer Discovery 3 1272-1285. (https://doi. org/10.1158/2159-8290.CD-13-0397)

Subbiah V, Kreitman RJ, Wainberg ZA, Cho JY, Schellens JHM, Soria JC, Wen PY, Zielinski C, Cabanillas ME, Urbanowitz G, et al. 2018 Dabrafenib and trametinib treatment in patients with locally advanced or metastatic BRAF V600-mutant anaplastic thyroid cancer. Journal of Clinical Oncology 36 7-13. (https://doi.org/10.1200/ JCO.2017.73.6785)

Tam S, Amit M, Boonsripitayanon M, Cabanillas ME, Busaidy NL, Gunn GB, Lai SY, Gross ND, Sturgis EM \& Zafereo ME 2017 Adjuvant external beam radiotherapy in locally advanced differentiated thyroid cancer. JAMA Otolaryngology - Head and Neck Surgery 143 1244-1251. (https://doi.org/10.1001/jamaoto.2017.2077)

Tesselaar MH, Crezee T, Swarts HG, Gerrits D, Boerman OC, Koenderink JB, Stunnenberg HG, Netea MG, Smit JW, NeteaMaier RT, et al. 2017a Digitalis-like compounds facilitate nonmedullary thyroid cancer redifferentiation through intracellular Ca2+, FOS, and autophagy-dependent pathways. Molecular Cancer Therapeutics 16 169-181. (https://doi.org/10.1158/1535-7163.MCT16-0460)

Tesselaar MH, Smit JW, Nagarajah J, Netea-Maier RT \& Plantinga TS $2017 b$ Pathological processes and therapeutic advances in radioiodide refractory thyroid cancer. Journal of Molecular Endocrinology 59 R141-R154. (https://doi.org/10.1530/JME-17-0134)

Tesselaar MH, Crezee T, Schuurmans I, Gerrits D, Nagarajah J, Boerman OC, van Engen-van Grunsven I, Smit JWA, Netea-Maier RT \& Plantinga TS 2018 Digitalislike compounds restore hNIS expression and iodide uptake capacity in anaplastic thyroid cancer. Journal of Nuclear Medicine 59 780-786. (https://doi.org/10.2967/ jnumed.117.200675)

Tiedje V, Stuschke M, Weber F, Dralle H, Moss L \& Fuhrer D 2018 Anaplastic thyroid carcinoma: review of treatment protocols. Endocrine-Related Cancer 25 R153-R161. (https://doi.org/10.1530/ ERC-17-0435)

Vanden Borre P, McFadden DG, Gunda V, Sadow PM, Varmeh S, Bernasconi M, Jacks T \& Parangi S 2014 The next generation of orthotopic thyroid cancer models: immunocompetent orthotopic mouse models of BRAF V600E-positive papillary and anaplastic thyroid carcinoma. Thyroid 24 705-714. (https://doi.org/10.1089/ thy.2013.0483)

Vezenkov L, Honson NS, Kumar NS, Bosc D, Kovacic S, Nguyen TG, Pfeifer TA \& Young RN 2015 Development of fluorescent peptide substrates and assays for the key autophagy-initiating cysteine protease enzyme, ATG4B. Bioorganic and Medicinal Chemistry 23 3237-3247. (https://doi.org/10.1016/j.bmc.2015.04.064)

Wallace DC 2012 Mitochondria and cancer. Nature Reviews: Cancer 12 685-698. (https://doi.org/10.1038/nrc3365)

Wang T, Goodall ML, Gonzales P, Sepulveda M, Martin KR, Gately S \& MacKeigan JP 2015 Synthesis of improved lysomotropic autophagy inhibitors. Journal of Medicinal Chemistry 58 3025-3035. (https://doi. org $/ 10.1021 /$ jm501586m)

Wang W, Kang H, Zhao Y, Min I, Wyrwas B, Moore M, Teng L, Zarnegar R, Jiang X \& Fahey TJ 3rd 2017 Targeting autophagy sensitizes BRAF-mutant thyroid cancer to vemurafenib. Journal of Clinical Endocrinology and Metabolism 102 634-643. (https://doi. org/10.1210/jc.2016-1999)

Wang J, Qi Q, Zhou W, Feng Z, Huang B, Chen A, Zhang D, Li W, Zhang Q, Jiang Z, et al. 2018a Inhibition of glioma growth by flavokawain $B$ is mediated through endoplasmic reticulum stress induced autophagy. Autophagy 14 2007-2022. (https://doi.org/10.108 0/15548627.2018.1501133)

Wang S, Wu J, Ren J, Vlantis AC, Li MY, Liu SYW, Ng EKW, Chan ABW, Luo DC, Liu Z, et al. 2018b MicroRNA-125b interacts with Foxp3 to induce autophagy in thyroid cancer. Molecular Therapy 26 2295-2303. (https://doi.org/10.1016/j.ymthe.2018.06.015)

Wei WJ, Shen CT, Song HJ, Qiu ZL \& Luo QY 2016 MicroRNAs as a potential tool in the differential diagnosis of thyroid cancer: a systematic review and meta-analysis. Clinical Endocrinology $\mathbf{8 4}$ 127-133. (https://doi.org/10.1111/cen.12696)

Wei WJ, Sun ZK, Shen CT, Song HJ, Zhang XY, Qiu ZL \& Luo QY 2017 Obatoclax and LY3009120 efficiently overcome vemurafenib resistance in differentiated thyroid cancer. Theranostics 7 987-1001. (https://doi.org/10.7150/thno.17322)

Wei W, Rosenkrans ZT, Luo Q-Y, Lan X \& Cai W 2018a Exploiting nanomaterial-mediated autophagy for cancer therapy. Small Methods 0 1800365. (https://doi.org/10.1002/smtd.201800365)

Wei WJ, Zhang GQ \& Luo QY $2018 b$ Postsurgical management of differentiated thyroid cancer in China. Trends in Endocrinology and Metabolism 29 71-73. (https://doi.org/10.1016/j.tem.2017.10.008)

Weitzel JM \& Iwen KA 2011 Coordination of mitochondrial biogenesis by thyroid hormone. Molecular and Cellular Endocrinology 342 1-7. (https://doi.org/10.1016/j.mce.2011.05.009)

White E, Mehnert JM \& Chan CS 2015 Autophagy, metabolism, and cancer. Clinical Cancer Research 21 5037-5046. (https://doi. org/10.1158/1078-0432.CCR-15-0490)

Xiang Y, Zhao J, Zhao M \& Wang K 2018 Allicin activates autophagic cell death to alleviate the malignant development of thyroid cancer. Experimental and Therapeutic Medicine 15 3537-3543. (https://doi. org/10.3892/etm.2018.5828)

Xing M 2013 Molecular pathogenesis and mechanisms of thyroid cancer. Nature Reviews: Cancer 13 184-199. (https://doi.org/10.1038/ $\operatorname{nrc3431)}$

Yan H, Bian A, Gao X, Li H, Chen Z \& Liu X 2018 Novel applications for an established antimalarial drug: tumoricidal activity of quinacrine. Future Oncology 14 1511-1520. (https://doi.org/10.2217/ fon-2017-0728)

Yang A, Herter-Sprie G, Zhang H, Lin EY, Biancur D, Wang X, Deng J, Hai J, Yang S, Wong KK, et al. 2018 Autophagy sustains pancreatic cancer growth through both cell-autonomous and nonautonomous mechanisms. Cancer Discovery 8 276-287. (https://doi. org/10.1158/2159-8290.CD-17-0952)

Yeager N, Klein-Szanto A, Kimura S \& Di Cristofano A 2007 Pten loss in the mouse thyroid causes goiter and follicular adenomas: insights into https://erc.bioscientifica.com

https://doi.org/10.1530/ERC-18-0502 (c) 2019 Society for Endocrinology Published by Bioscientifica Ltd. Printed in Great Britain 
thyroid function and Cowden disease pathogenesis. Cancer Research 67 959-966. (https://doi.org/10.1158/0008-5472.CAN-06-3524)

Yeo SK, Paul R, Haas M, Wang C \& Guan JL 2018 Improved efficacy of mitochondrial disrupting agents upon inhibition of autophagy in a mouse model of BRCA1-deficient breast cancer. Autophagy $\mathbf{1 4}$ 1214-1225. (https://doi.org/10.1080/15548627.2018.1460010)

Yi HS, Chang JY, Kim KS \& Shong M 2017 Oncogenes, mitochondrial metabolism, and quality control in differentiated thyroid cancer. Korean Journal of Internal Medicine 32 780-789. (https://doi. org/10.3904/kjim.2016.420)

Yi H, Ye T, Ge M, Yang M, Zhang L, Jin S, Ye X, Long B \& Li L 2018 Inhibition of autophagy enhances the targeted therapeutic effect of sorafenib in thyroid cancer. Oncology Reports 39 711-720. (https:// doi.org/10.3892/or.2017.6118)

Youle RJ \& Narendra DP 2011 Mechanisms of mitophagy. Nature Reviews: Molecular Cell Biology 12 9-14. (https://doi.org/10.1038/ nrm3028)

Yu W, He X, Ni Y, Ngeow J \& Eng C 2015 Cowden syndrome-associated germline SDHD variants alter PTEN nuclear translocation through SRC-induced PTEN oxidation. Human Molecular Genetics 24 142-153. (https://doi.org/10.1093/hmg/ddu425)

Yu W, Ni Y, Saji M, Ringel MD, Jaini R \& Eng C 2017 Cowden syndrome-associated germline succinate dehydrogenase complex subunit D (SDHD) variants cause PTEN-mediated down-regulation of autophagy in thyroid cancer cells. Human Molecular Genetics 26 1365-1375. (https://doi.org/10.1093/hmg/ddx037)

Yu Y, Yu X, Fan C, Wang H, Wang R, Feng C \& Guan H 2018 Targeting glutaminase-mediated glutamine dependence in papillary thyroid cancer. Journal of Molecular Medicine 96 777-790. (https://doi. org/10.1007/s00109-018-1659-0)

Zbuk KM \& Eng C 2007 Cancer phenomics: RET and PTEN as illustrative models. Nature Reviews: Cancer 7 35-45. (https://doi.org/10.1038/ nrc2037)

Zhang Y, Yang WQ, Zhu H, Qian YY, Zhou L, Ren YJ, Ren XC, Zhang L, Liu XP, Liu CG, et al. 2014 Regulation of autophagy by miR-30d impacts sensitivity of anaplastic thyroid carcinoma to cisplatin. Biochemical Pharmacology 87 562-570. (https://doi.org/10.1016/j. bcp.2013.12.004)

Zhang R, Hardin H, Chen J, Guo Z \& Lloyd RV 2016 Non-coding RNAs in thyroid cancer. Endocrine Pathology 27 12-20. (https://doi. org/10.1007/s12022-016-9417-8)

Zhang X, Wang C \& Lin Y 2018 Pilot dose comparison of apatinib in chinese patients with progressive radioiodine-refractory differentiated thyroid cancer. Journal of Clinical Endocrinology and Metabolism 103 3640-3646. (https://doi.org/10.1210/jc.201800381)

Received in final form 9 January 2019

Accepted 21 January 2019

Accepted Preprint published online 21 January 2019 (c) 2019 Society for Endocrinology Published by Bioscientifica Ltd. Printed in Great Britain 